\title{
news from our chapters
}

\section{Asheville}

The 84th chapter meeting was held on 1 May at the Hungry Bull Restaurant. Chairman Tom Karl called the meeting to order; there were 19 members and six guests present.

Following the business meeting, Karl introduced the evening's speaker, Donald Barnes. Barnes is an architect and a professor at North Carolina State University. He holds a doctorate in environmental design from Texas A\&M University.

Barnes' presentation, "Energy in Building," traced the evolution and decline of fuels through the Greeks, Romans, and colonists, who "ran out of wood," to a Cornell University Professor who felt, in 1901 , that we would run out of coal. Now we worry about running out of oil and natural gas. So we are looking at two "old fuels" for the future: conservation and passive design. To take advantage of them we must design buildings for specific environments. Solar Spec, a film produced by the North Carolina Energy Institute, presented the design concepts.

Good passive design starts with an understanding of the site's climatic conditions, heating and cooling requirements, wind, and solar resource. The available solar resource depends on day length, humidity, cloud cover, elevation, pollution, and the immediate surroundings.

Three major components in a solar system are collection, storage, and transfer of solar energy. Solar energy may be stored effectively in high density media such as masonry, stone, or water. A major goal of a passive system is to provide enough thermal mass to absorb the radiation quickly, conduct heat slowly, and release it as needed. The storage media may also act as a transfer media. Active systems rely on pumps or fans to move the heat transfer medium whereas passive solar systems use the natural energy flow of radiation, conduction, and convection for heat transfer.

Three types of passive systems were described: direct gain (south facing glass wall allowing insolation to penetrate the living space); indirect gain (trombe wall), and insolated gain (solar greenhouse). The film also dealt with ventilation, infiltration, berming, shading and reflecting techniques, and movable insulation.-Charles $D$. Jones, Secy.

\section{El Paso-Las Cruces}

On 14 April the chapter met at Furr's Cafeteria on Mesa St., El Paso, Tex. Willis Webb of the University of Texas-El Paso (UTEP) requested thermospherics material for the UTEP archives.

The following people were nominated and elected as new officers for 1981-82: President, Steve Cohn; Vice-President, Orville Creasey; and Secretary-Treasurer, Stuart Bowersox. The newly elected president, Steve Cohn, introduced Dr. Dowdy of the Mechanical Engineering Department at UTEP. Dowdy discussed UTEP's solar energy program.

The 16 May meeting was held at Marvin Kays' house in Las Cruces, $\mathrm{N}$. Mex. It was a barbecue set up to get new members acquainted

\footnotetext{
${ }^{1}$ Meeting reports received at Headquarters before 15 July 1981 are included. Copy from chapter representatives should be typed double-spaced and submitted in duplicate; photos accompanying reports should be black and white.-News Ed.
}

with old members. Three new members are Clayton Wright, Adarsh Deepak, and Fred Horning.-Stuart Bowersox, Secy.-Treas.

\section{Farthest North}

In the vast Alaskan wilderness, tracking dogs have been vitally important in rescue operations and subsistence hunting. One frequently overlooked factor in the tracking ability of dogs is meteorology. This quaint phase of applied Arctic meteorology was the subject of the 29 June chapter meeting.

Sue Ann Bowling of the Geophysical Institute, University of Alaska, Fairbanks, discussed the effects of meteorological parameters on the performance of tracking dogs. Low-level dispersion, in the first few meters of the atmosphere, is the most critical factor. In the interior of Alaska, low-level dispersion is very poor during the long winter, and tracking dogs perform at their best during such conditions. The effect of forest cover can be pronounced in reducing wind, and thus improving tracking performance. Strong surfacebased inversions are common in the interior during winter, and these aid considerably in tracking. Oldtimers have pointed out that a large caribou herd can leave a trail of ice fog when it is on the move during 40-below weather. The ice fog is the visible manifestation of their passage. The invisible scent that accompanies it is not noticeable to humans, but is easily detected and followed over long distances by trained tracking dogs.

Alaskans, who are fond of boasting of their land, can thus add another item to their list: the "tracking weather" in the interior during winter is probably the best in the United States.-Ted Fathauer, Secy.

\section{Indiana}

The last chapter meeting of the year was held in Indianapolis at the Ramada Inn on 5 May. The meeting began with cocktails followed by dinner; members were encouraged to bring a spouse or guest.

The meeting was officially called to order by Chairman John Curran. Old business related to the proposed changes to the By-laws of the National AMS Constitution. (See AMS BuLleTIN 61, 1446.) Marline Roberts explained the proposed changes, and the floor was opened for discussion.

The chapter expressed great pleasure in the increase in meteorological exhibits at science fairs. The judges also found that each entrant is becoming more involved in his or her exhibit. Each meteorological exhibit winner will receive a "Certificate of Outstanding Achievement" and a one year subscription to Weatherwise as an award for an outstanding project.

Special recognition goes to Celeste Ewalts of Lafayette, Ind., who won the overall science fair award for her project, "Influence of Weather on Grain Elevator Explosions."

New officers were elected for the 1981-82 year. They are Chairman Craig Edwards, Program Chairperson Marline Roberts, and Secretary/Treasurer Barry A. Smith.

The evening's highlight was a tour by David James of the WRTV Channel 6 news studio. James was recently employed as the morning and noon meteorologist for WRTV and is an active chapter member. Of special interest to chapter members was the equipment used in 


\section{Th Conference on 1 Probability and Statistics in Atmospheric Sciences}

\author{
October 9-12, 1979 \\ Banff, Alta., Canada
}

The Sixth Conference on Probability and Statistics in Atmospheric Sciences, sponsored by the American Meteorological Society, was held 9-12 October 1979 in Banff, Alta., Canada. Sessions on "Design and Evaluation" were held jointly with the Seventh Conference on Inadvertent and Planned Weather Modification. Over 70 papers are included in the preprint volume under the following session topics:

Statistics in meteorological observations • Statistical forecasting studies: Dynamical, synoptic, regression, logit, discriminant analysis - Design and evaluation-Statistical methodology, evaluation of operational programs, plans and designs, evaluations and reanalyses, structure of experimentation - Classification - Forecast evaluation and verification - Weather modeling by statistics - Climate modeling by statistics - Time series and Markov processes - Theoretical statistical considerations

\section{9 pages}

\section{\$15 AMS Members \\ $\$ 20$ Nonmembers (add $\$ 2.00$ postage is handling)}

Send order and remitlance to:
AMERICAN
METEOROLOGICAL SOCIETY
45 Beacon St.
Boston, Mass. 02108

televising. Some of the equipment used by the meteorologist consisted of color imagery from satellite and the color radar. Channel 6 was the first station in the central Indiana area to incorporate color radar into the news program.

The group then viewed an actual newscast by Bob McLain, lead meteorologist at WRTV. McLain, who has the AMS Seal of Approval for television broadcasting, demonstrated that a complete forecast can be made within a matter of minutes. Questions and comments were entertained following the newscast.-Barry $A$. Smith, Secy.-Treas.

\section{Omaha-Offutt}

The final chapter meeting of the 1980-81 season was held on Tuesday, 19 May on board the river boat Belle of Brownville. The Belle departed its berth at Haworth Park in Bellevue, Neb. at 7:00 p.m. for a Missouri River cruise.

After dinner, which was catered for the 132 members and guests, Chairman Larry Johnson presided over a short business meeting. The usual committee reports were omitted. The winner of the final forecasting contest of the year was Ken Dewey. He successfully forecast the total rainfall of the North Omaha Weather Station between 0000z GMT 3 April and 0000z GMT 17 May 1981; for this feat he was awarded a rain gage donated by a local TV station. The winner of a dinner for two at a local dinner theater was Harvey McInnis; he accumulated the most points in the forecasting contests during the season.

Officers elected for the 1980-81 season were installed; then newly elected Chairman Fred Lewis presented the outgoing officers with plaques in appreciation for their good work. Certificates of Appreciation were presented to individuals who helped with chapter business during the past season.

The Belle returned to its berth at 9:00 p.m., concluding a very interesting and educational season for the chapter.-Harvey $D$. McInnis, Recording Secy.

\section{Southern Arizona}

The chapter held its third meeting of the 1980-81 season on 27 March at the Black Angus Restaurant, Tucson, Ariz.; 26 members and guests attended. The meeting was called to order by President James McKenzie.

The guest speaker was Michael Goodrich, weathercaster for the Tucson, Ariz., NBC station KVOA-TV, Channel 4. He spoke about the requirements for obtaining the AMS Seal of Approval for TV newscasters. He related his experiences in meeting these requirements and talked about some of the test questions. He also discussed the relation of the TV audience to his weather presentations.

A short business meeting followed Goodrich's talk, during which a selection committee was formed to determine candidates for next season's officers.

The 29 May dinner meeting of the chapter was held at the Officers' Club at Davis-Monthan Air Force Base, Tucson; 19 members and guests attended.

During the business meeting which followed the dinner, Theodore Cogut, Chairman of the Nominating Committee, presented the slate of candidates for 1981-82 officers. President James McKenzie asked for any additional nominations. A voice vote was taken and the following were unanimously elected: Pesident - Gene T. Coryell, ASARCO; Vice-President - David L. Koehler, Magma Copper Company; Treasurer - Paul Ostapuk, Phelps Dodge Corp.; Secretary - Robert F. Clark. McKenzie thanked all of the chapter 
members and officers who had contributed to making the 1980-81 year a successful one; he thanked Lt. Pamela Betrosoff for making the dinner arrangements with the Officers' Club; he then congratulated the new officers and turned the meeting over to his successor, Gene Coryell. The new president discussed tentative plans for the coming year. - David L. Koehler, Secy-Treas.

\section{Twin Cities}

At the 19 February chapter meeting, Noel Petit gave a short presentation on "A Numerical Ocean Prediction Model." The schedule of regional Minnesota Science Fairs in March and April was brought before the chapter to solicit volunteers for judging and awarding the chapter's Special Award to students with outstanding projects in meteorology and climatology.

Then Dean Braatz of the Twin Cities River Forecasting Center (RFC) and John Seeman, U.S. Army Corps of Engineers, addressed the club. The North Central RFC began operations in January 1980. It collects data in North Dakota, Minnesota, Wisconsin, Michigan, Iowa, Illinois, Indiana, and Missouri; and forecasts for approximately 500 points over a 340000 square mile area. The RFC provides over 65000 forecasts per year to Weather Service Forecast Offices for public dissemination and to governmental agencies.

Precipitation data are provided in large part by a volunteer network of observers. The density of the network averages less than one rain gage every 400 square miles. $90 \%$ of the stations take only daily observations, and less than $5 \%$ of the network is automated. Data gathering by other governmental agencies is generally not coordinated to a standard observation time.

Since the late 1960 s, data have been analyzed with the Antecedent Index Model, a computerized version of the original hand calculation procedure. Among RFC's goals for the 1980s is the implementation of the Sacramento Soil Moisture Accounting (SMA) Model to replace the Antecedent Index Model. The Center is also preparing to get its own computer for in-house forecasting operations. Braatz also indicated that data from the Airborne Gamma Radiation Program measuring water equivalence of the snow pack will be incorporated into RFC's data base.

John Seeman described the procedures used by the RFC to forecast runoff and flow in 442 runoff zones of the Upper Mississippi and its tributaries; the Souris, Red, and Rainy Rivers; and Great Lakes drainage. The Antecedent Precipitation Index (API) accounts for soil moisture and determines runoff and response in the sub-basins using the unit hydrograph and a routing model. Seeman presented the methodologies of both the API and the SMA. The latter would provide an enhanced representation of the soil moisture parameter.

Braatz and Seeman estimated that the average taxpayer in one year pays the equivalent of a Big Mac, Fries, and a Coke to receive all the weather services available through the federal government.

The 19 March meeting was addressed by chapter Vice-President Tom Fahey of Northwest Airlines and by chapter Secretary Doug Kohl of Anoka Vocational-Technical Institute.

Fahey reviewed the Puget Sound Convergence Zone. Twenty to thirty times a year, covergence develops over the Sound, resulting in low ceiling strata and localized precipitation. This phenomenon develops with stable conditions and west or northwest winds such that the winds are forced around rather than over the Olympia Mountains and then are blocked by the topographical barrier of the Cascade Mountains to the west of the Sound.

Doug Kohl gave a very informative history and explanation of the evolution of computers. He provided actual examples of circuitry, from the original vacuum tubes to transistors to integrated circuitry to ferro-magnetic material and floppy and rigid discs. He explained the binary basis of computer storage of information and the corresponding size and abilities of computers. Kohl conjectured that the next generation will be computer-literate by the third grade!

The 16 April meeting was a presentation on the KSTP Doppler radar by former chapter Secretary John Dooley of KSTP.

Dooley had hoped to have the chapter at KSTP for the April meeting to demonstrate the new Doppler radar; however, it was not yet working at the time of the meeting. KSTP transmits the radar data directly to the National Weather Service-Twin Cities office under a mutual cooperation agreement.

Dooley gave a fascinating explanation of the problems and nuances of the Doppler. The primary characteristic of Doppler radar is that extensive experience with the radar image is required to overcome image trickery, principally the "folding" of echoes even after computer refinement. A color scheme depicts the motion toward or away from the radar. Consequently, half the screen is represented in an opposite fashion from the other half because it has already passed over and is now generally moving away from the radar. Experience, especially in reading the folding over effect, is the essential factor in proper interpretation of the Doppler image. The shortage of personnel at NWS and demands on the office during storm periods make use of the Doppler radar for NWS tornado forecasting only a possibility for the future.-Carol L. Strong, Secy.

\section{Utah}

The 25 March meeting was held at the University of Utah in the Fletcher Building. J. Mark Fair, Western Region Agricultural Meteorologist and a chapter member, spoke on initiating an operational meteorology program in a third world country.

Fair spent six weeks in Jordan during the fall of 1980 helping to design a service that would produce long-term benefits for Jordanian agriculture and consequently its economy. By U.S. standards, Jordan is still a developing country, despite the fact that intensive agriculture has been going on there for 2000 years. Agriculture is the mainstay of the Jordanian economy since it has no petroleum or natural resources except phosphates. Consequently, the weather has a direct relationship to the country's economic well-being.

The main weather-related agricultural problems are frost for winter- and cold-sensitive plants, handling and utilization of water, and lack of understanding of the relationship between weather and agriculture. The Jordanian government has an agricultural weather system set up to measure winds, radiation, soil temperature, soil moisture, and evaporation. The Jordanian meteorological services were well staffed; however, they did not have the technological knowledge to utilize the information available from the agricultural measurements system.

The primary support mechanism the Jordanian meteorological services need to provide to the agricultural user is frost forecasts. In order to do this, the data collected must be used with technical expertise. Additionally, the meteorological services need to be expanded to include all aspects of agricultural services and to educate users as to the proper use of available information. Building a data base is necessary as well, as is improving communications to relay information to users. When these improvements are made, the Jordanian meteorological services can be utilized to support the national economy.

Fair also showed slides of the Jordanian landscape and historic landmarks as part of his discussion.

Several orders of chapter business were addressed following Fair's presentation. Volunteers were taken to judge at several science fairs being held in the next two weeks. Nominations were taken from the membership for elections of the 1981-82 chapter Executive Board.-Barbara MacRae, Secy.-Treas. 


\section{Wright Memorial}

The chapter, led by Chairman Lt. Col. Ronald Brown, Vice Chairman James Leurs, and Secretary-Treasurer Capt. Ronald Rodney, just completed a very rewarding year. During the 1980-81 year the chapter met for eight luncheons and one evening meal. The following summarizes each meeting:

John Flynn of the U.S. Forest Service spoke at the first meeting of the 1980-81 season. His 24 October talk at the Seven Nations Restaurant on "The Magnitude of the Urban Heat Island Effect in Dayton" was well received by the membership.

Mollie Hughes, special assistant to the Dayton Climatic Project, presented an interesting talk in November on her work in improving the Dayton climate. This luncheon at the Wright-Patterson Air Force Base (AFB) Officers' Club, one of the highlights of the year, was enjoyed by 34 members.

At the December luncheon at Annarino's, members previewed Jim Leurs' and Patrick Haines' work on "Aircraft Landing AccidentsWind Shear is Not the Answer?" Their work at the University of Dayton Research Institute was featured the following month in Aviation Week \& Space Technology.

"What is RAPCA?' was the subject for Dena Michaelson's January presentation at a smorgasboard luncheon at the Wright-Patterson AFB Officers' Club. Michaelson of the Regional Air Pollution Control Agency spoke to 30 well-fed members on how the agency works to improve Dayton's air quality.

Robert Dean, staff meteorologist at the Aeronautical Systems Division at Wright-Patterson AFB, spoke on "The 1980 U.S. Executive Environmental Quality and Natural Resources Seminar" at the chapter's February luncheon at the Holiday Inn in Fairborn. Dean, who had recently returned from this two week seminar at the University of California-Berkeley, had some very enlightening remarks on the nation's energy deficit.

Lt. Dan Vial, Staff Weather Officer to the 4950th Test Wing at Wright-Patterson AFB, talked on "Weather Support to the Air Force Systems Command Advanced Research Instrumented Aircraft (ARIA)" at the March luncheon at the Wright-Patterson Officers' Club. Lt. Vial's viewgraph presentation was enlightening to both military and civilians.

"Severe Weather" was the topic for a panel discussion the evening of 30 April. Fifty-three members and their guests enjoyed a fine meal and program at the Holland House Supper Club. Five experts from the area discussed their roles in severe weather: James DewMeteorologist In Charge, Dayton Office of the National Weather Service; Lt. Col. James Calcote-Commander of Det 15, 15 Weather Squadron (Base Weather) Wright-Patterson AFB; Carl Nichols-Meteorologist, WDTN Channel 2 TV; Michael SnappStaff Meteorologist, Aeronautical Systems Division, and expert on the next generation of weather radar; JoAnne Finfrock-Miami Valley Disaster Service Authority.

At the 2 June meeting Richard Groeber of Dick's Weather Service talked about his private weather consulting service. His candid remarks about his unique experiences were enjoyed by 22 members and guests. Additionally, officers for the 1981-82 year were elected. These officers will assume their new duties in September: Chairman, Maj. Edward Tomlinson; Vice-Chairman, Maj. Michael Snapp; Secretary-Treasurer, Lt. Dan Vial.

The chapter's 55 members are looking forward to another enlightening year of programs after the summer recess.-Ronald Rodney, Secy.-Treas.

\title{
Preprint Volume
}

\section{CONFERENCE ON FLASH FLOODS: HYDROMETEOROLOGICAL ASPECTS}

\section{May 2-3, 1978}

Los Angeles, Calif.

The Conference on Flash Floods: Hydrometeorological Aspects, sponsored by the American Meteorological Society with the support of the American Geophysical Union, was held 2-3 May 1978 in Los Angeles, Calif. "The conference and the papers provide a means of assessing the current status of research and service programs dealing with the hydrometeorological aspects of flash floods, a major problem in the United States."

Over 30 papers are arranged under the following topics:

\author{
Meteorological Analyses \\ Meteorological Observations \\ Hydrometeorology \\ Hydrology \\ Case Studies \\ Johnstown Flash Flood
}

200 pages

$\$ 15$ AMS Members $\$ 20$ Nonmembers

(add $\$ 2.00$ postage/handling)

Send order and remittance to:

AMERICAN METEOROLOGICAL SOCIETY, 45 BEACON ST., BOSTON, MASS. 02108 